Univerza v Ljubljani

Filozofska fakulteta

evaa.krystufek@gmail.com

\title{
PODOBA ŽENSKE V LIRIKI IVANA CANKARJA
}

Članek se ukvarja z upodabljanjem ženskih likov v liriki Ivana Cankarja. S primerjalno analizo kronološko spremljamo razvoj ženskega lika od Cankarjevih najbolj zgodnjih, še neobjavljenih pesmi pa vse do Erotike, ki se ji v članku posvetimo najbolj natančno. Preko pesmi ugotavljamo, kako se je spreminjal osebni Cankarjev odnos do vloge ženske $\mathrm{v}$ odnosu do moškega in njene vloge $\mathrm{v}$ družbi, pri čemer istočasno spoznamo takratno dojemanje ženske $v$ širši slovenski javnosti, ki se je na Cankarjevo Erotiko burno odzvala.

Kljucne besede: Ivan Cankar, Erotika, dekadenca, motiv ženske, slovenska poezija

Ivan Cankar je, poleg Otona Župančiča, prvi slovenski modernist, ki žensko umesti med osrednje like svojih del. Ženske v svojih proznih in dramskih besedilih pogosto uporabi kot proti pol dominantnim, moškim likom, ki jih s svojimi čari vodijo v prepad ali pa kot bogaboječe matere, ki se s ponižnostjo in odrekanjem žrtvujejo za dobro svojih sinov.

Zgoraj naslikana podoba ženske v Cankarjevi prozi in dramatiki pa se močno razlikuje od podobe v njegovi liriki. Cankarjeva lirika, pri kateri se je naslonil na evropsko dekadenco in senzualizem, tako pomeni prav poseben prelom tudi iz feminističnega vidika, saj se je prvi ukvarjal z žensko kot s čutnim, erotičnim bitjem, ki v svojem čustvovanju in hotenju ni podrejena moškemu, ampak predstavlja samostojno entiteto, z lastnimi željami in čustvovanjem.

Razvoj ženske podobe v Cankarjevi liriki lahko zelo jasno vidimo preko nekaterih objavljenih in neobjavljenih pesmih, ki so nastale pred Erotiko. V njih lahko opazujemo, kako Cankar preide iz opisovanja ženske kot čiste, sramežljive in predvsem nedotakljive device $\mathrm{k}$ opisovanju ženske, ki moškim buri duhove in domišljijo, z namenom ugajanja in doseganja ciljev.

Popolno čutno osvoboditev pa ženska čutnost doživi v pesniški zbirki Erotika iz leta 1899, kjer se brez sramu predaja telesni ljubezni 
in je popolnoma enakovredna svojemu ljubimcu. Ženska do moškega čuti enako poželenje, ki se ga ne sramuje, odnosu pa se preda zaradi lastne želje. Cankar skozi štiri cikle raziskuje žensko čutnost in čustva, ki jih dekadenčni motivi in razpoloženje dokončno osvobodijo okovov zadržanosti in sramežljivosti, ki so pred tem v slovenski liriki predstavljali normo pri opisovanju ženske. Motiv ženske je v Erotiki tako močno zaznamovan $\mathrm{z}$ dekadenco, da se na nekaterih mestih žensko hotenje in telesnost elegantno preplete z božanskostjo in misticizmom, ki pa je popolnoma drugačen od kalupa, v katerem se njena vloga znajde v Cankarjevi prozi in dramatiki.

\author{
Cankarjeva poezija pred erotiko \\ »Mirno glédaš me devica, mirno pred menoj stojiš ..."
}

Zgornji verz je začetek pesmi Očitanje, ki jo je Cankar napisal leta 1891 (Cankar 1967: 327). Je ena izmed neobjavljenih Cankarjevih pesmi in pesniških poskusov, ki sama po sebi ne prinaša neke velike estetske vrednosti, da pa nam precej nazorno sliko o Cankarjevem dojemanju ženske nekaj let pred prvo izdajo Erotike.

V pesmi Očitanje srečamo mlado, lepo in nedolžno žensko, ki s svojo božansko pojavo spravlja nesrečno zaljubljenega pesnika v trpljenje in obup. Ženska je prikazana kot oboževan objekt, katerega edina funkcija je spravljanje pesnika v nesrečo. Tako slikanje ženske je prisotno tudi v poeziji Franceta Prešerna in prav Cankarjevo pesem Očitanje lahko primerjamo s Prešernovo pesmijo Pod oknam.

\section{OČITANJE}

Mirno glédaš me devica, mirno pred menój stojiš; da kar právim nij resnica mirno méni govoriš.

Moje srce je nesréčno ko ljubiti te ne smém; žálost trla bo me véčno in vmorila bo me, vém.

Razpršila zóbna síla je ljubézni sréčen raj. Prósim deklica te mila dàj, ozri se náme vsàj.

\section{POD OKNAM}

Luna sije, kladvo bije trudne, pôzne ure že ... Pred neznane srčne rane meni spati ne pusté.

Ti si kriva, ljubezniva, deklica nevsmiljena! Ti me raniš, ti mi braniš, da ne morem spat'domá. 
In ta síla ljuboválna

bil je duh nezvésti tvój.

Zdaj mori me tóga žálna

in vmorjén vže duh je moj.

Cankar 1967: 155
Obraz mili

tvoj po sili

mi je vedno pred očmi;

zdihujoče

srce vroče

vedno $k$ tebi hrepeni.

K oknu pridi!

Drug ne vidi,

ko nebeške zvezdice;

se prikaži,

al sovraži

me srce, povej, al ne!

Up mi vzdigni,

z roko migni,

ak bojiš se govorit'...

Ura bije,

k oknu ni je,

kaj sirota čem storit’!

V hram poglejte,

mi povejte,

zvezde, al res ona spi!

Al posluša,

me le skuša,

al za druzega gori.

Ako spava,

naj bo zdrava!

Ak me skuša, nič ne dé;

po nje 'zgubi,

ako ljubi

druz'ga, počlo bo srcé.

(Pod oknam - Wikivir)

Če primerjamo Prešernovo in Cankarjevo pesem ugotovimo, da je ženska, ki jo opisujeta skorajda identična. Lepa, na videz nedolžna, mila deklica, v katero je pesnik nesrečno zaljubljen in se obsesivno bori s svojim ljubosumjem. Čeprav, na prvi pogled pesnik v ospredje postavlja ženski lik, pa je v resnici središče dogajanja moški, tj. pesnik. Ženska je kot objekt pri obema postavljena za moškim subjektom, ki nam izpoveduje svoje doživljanje, čustvovanje in poželenje, ki ga čuti do objekta. Motiv ženske, kljub božanski pojavi, predstavlja krivca za 
moško nesrečo, torej kot proti pol ubogemu trpečemu moškemu (nekakšen volk v ovčji preobleki). Zanimivo pri negativni podobi ženske je tudi, da je njena podoba izrazito pasivna. Vso dinamiko vanjo vlije moški s svojim očitanjem in insinuacijami glede njene zvestobe. Četudi je ženska prikazana kot karakterno negativna, pa vsekakor ne smemo trditi, da je moškemu inferiorna. Ravno obratno, naslikana je kot preračunljiva in nezvesta, ki se s svojim moškim oboževalcem igra, on pa jo prosi vsaj za pozornost, pri čemer samega sebe dojema kot podrejenega njeni božanski podobi. ${ }^{26}$

Primerjava Cankarjeve in Prešernove pesmi nam torej dokazuje, da je v najzgodnejši liriki Ivan Cankar žensko dojemal zelo romantično in podobno kot Prešeren. Zelo podobno sliko ženske kot božanske, nedosegljive prikazni, v zgodnji Cankarjevi liriki najdemo tudi v pesmih: Tvoj pogled (1891), Poljub (1891), Slutnja (1891), Prošnja (1891) ...

»In vendar, dèkle, ni mi srce mrlo, ko brez bil je pógled tvoj!«

Leta 1892 je Ivan Cankar v reviji Vertec objavil svojo prvo pesem Pes, maček in miši, pri kateri je snov črpal iz ljudskega izročila. Zanjo je prejel pozitivno kritiko, kar ga je k pisanju pesmi še dodatno spodbudilo. Kljub temu, da je že takrat vedel, da njegov jaz pride najbolj do izraza v prozi in dramatiki, je pred izidom Erotike, leta 1899, objavil nekaj pesmi, predvsem z ljubezensko tematiko (Cankar 1967: 366367). Če opazujemo žensko podobo v liriki tega obdobja, ugotovimo, da je ženska večinoma še vedno upodobljena kot (včasih nedosegljiv) objekt oboževanja, vendar je v svojem obstoju in položaju že nekoliko bolj enaka svojemu moškemu občudovalcu. V nekaterih pesmih lahko začnemo slutiti, da pesniku celo vrača ljubezen. Iz požiralke moških, ki s pretvezo nedolžnosti požira moške, se prelevi v prijetno mladenko, ki jo pesnik sicer občuduje, a v njej vidi tudi preprosto, človeško plat. To lahko pripišemo Cankarjevi takratni zaljubljenosti v Ano Lušinovo, ki je bila v takratnem času navdih za večino njegovih ljubezenskih pesmi, ali pa začetnemu spoznavanju evropskega senzualizma. Čeprav je Cankar v pismu Otonu Župančiču izjavil, da mu senzualistično pesništvo ni

\footnotetext{
${ }^{26}$ Izmed Cankarjevih zgodnjih pesmi velja na kratko izpostaviti tudi pesem Materi, ki je ena izmed redkih Cankarjevih pesmi, ki prikazuje žensko kot mater. To je ena izmed redkih pesmi, kjer se podoba ženske v Cankarjevi liriki približa podobi, kot jo slika $\mathrm{v}$ prozi in dramatiki. Mati je tudi v tej pesmi prikazana kot brezmejno ljubeča in trpeča ženska, ki se je celo življenje žrtvovala za svojega sine, ta pa kljub temu trpi in se bori $\mathrm{z}$ večnim neuspehom.
} 
blizu (Bernik 1968: 170), pa se njegovemu vplivu na liriko verjetno ni mogel povsem izogniti.

Kot primer nekoliko spremenjenega dojemanja ženske lahko navedemo pesem Triolet iz leta 1894:

\author{
In vendar, dèkle, ni mi srce mrlo, \\ ko brez ljubezni bil je pógled tvoj! \\ Razrušil se je lepi sèn nocoj, \\ in vendar, dèkle, ni mi srce mrlo! \\ Kakó sem upal, da ves čar bi svoj \\ nebó ljubezni kdaj odprlo; \\ in vendar, dèkle, ni mi srce mrlo, \\ ko brez ljubezni bil je pógled tvoj! - \\ Nikdár srcé ni moje bilo srečno, \\ zakaj li srečno bi bilo sedaj? \\ Za njé ustvarjen ni na zemlji raj, \\ nikdár srce ni moje bilo srečno! \\ Če le za hip bi pilo sreče slaj, \\ od njega bi potem drhtelo večno. \\ Nikdár srcé ni moje bilo srečno, \\ zakaj li srečno bilo bi sedaj! \\ (Cankar 1967: 134)
}

Ženska v pesmi Triolet ponovno ne zavzema glavne vloge, niti se z njeno pojavo in dojemanjem sveta ne ukvarja. Drugačna od njegovih prvih pesnitev je njena podoba zgolj $\mathrm{v}$ tem, da njena nima več tako negativnega značaja in njena izbira ne vodi za seboj moškega subjekta $\mathrm{v}$ propad.

$\mathrm{S}$ tem v mislih lahko beremo tudi pesem Kancioni $^{27}$, ki je nastala istega leta. V tej pesmi prav tako pesnik opisuje nesrečno ljubezen, a vendar v njej ni nikjer razvidno, da je za to nesrečno ljubezen kriva ženska. Žensko podobo opiše v verzu: »Oh, v vsem trpljenju mojem si ledena. Ledena kakor krasen kip boginje /.../« (Cankar 1967: 136). Kljub tako opisani podobi pa ne dobimo občutka, da bi žensko pesnik dojemal kot boginjo v nadrejenem položaju, kot je je v pesmi Očitanje, ampak v njemu enakem položaju. Sta zgolj mladenič in mladenka, ki ne moreta uresničiti svoje ljubezni.

Naslednja pomembna pesem, ki je bila objavljena pred Erotiko je pesem Helena, ki je bila prvič objavljena v Ljubljanskem zvonu leta 1896. Prvotno je bila vključena v cikel Helena, ki je del Erotike, pozne-

${ }^{27}$ Glej Prilogo. 
je pa jo je Cankar iz zbirke umaknil in je ni vključil v nobeno izdajo pesniške zbirke (Cankar 1967: 371). V pesmi je opisana ljubezen, za katero lahko domnevamo, da obstaja ženski neznana. Gre za nagovor Amorja, ki ga pesnik obtožuje za svojo nesrečo. V pesmi, ki sicer o ženski ne spregovori neposredno, vendar je njena prisotnost jasna skozi pripoved. Prav v tej in v pesmi lahko počasi zaslutimo Cankarjev premik k dekadenci, o čemer pričajo slikoviti verzi, ki svoj vrh dosežejo v Erotiki.

\section{Erotika}

Leta 1899 je izšla edina Cankarjeva pesniška zbirka Erotika, ki je v Sloveniji vzdignila ogromno prahu. Cankar je že s samim naslovom Erotika izzval veliko neodobravanje med ljubljansko desnico in le ugibamo lahko, ali je ta naslov izbral z namenom provokacije (Cankar 1967: 252). Pesniška zbirka je sicer sestavljena iz štirih pesniških ciklov: Helena, Iz lepih časov, Dunajski večeri in Romance, ki jih bomo $\mathrm{v}$ tem delu tudi podrobneje obravnavali.

\section{»Helena pa odpré okó, — zasmeje se takó ljubó«}

Zgornje besede pripadata zadnjima dvema verzoma devete pesmi, v ciklu Helena in odlično ilustrira vzdušje in odnos, ki ga pesnik goji do ženske - Helene. Pesmi so sicer že pred pesniško zbirko posamezno izhajale v Ljubljanskem zvonu, nastale pa so kot posledica Cankarjeve ljubezni do učiteljice Helene Pehanijeve (Cankar 1967: 299).

Helena ne predstavlja nekega popolnoma novega ali revolucionarnega pogleda na žensko figuro, ampak še vedno ostaja pri slikanju podoben pesmim pred Erotiko. Edina stvar, ki se spremeni je, da se v aktivni vlogi občasno znajde tudi Helena, ki ne predstavlja več pasivnega objekta, ki ga pesnik samo občuduje, ampak se te pasivnosti počasi osvobaja in na čase postane celo dinamična in aktivna. Lik Helene ostaja v malenkost privzdignjenem in močno idealiziranem položaju, a v primerjavi s prejšnjimi pesmimi razlika med žensko in moškim postaja vse manjša. V ospredju so sicer večino časa še vedno občutki moškega, sem in tja dobimo bežen vpogled tudi v žensko hotenje. V ciklu Cankar opisuje predvsem nesrečno ljubezen do popolne ženske, ki pa ni več nedotakljiva, ampak se pesnik z njo zabava, pogovarja, se jo dotika, s čimer Cankar distanco med objektom oboževanja in subjektom bistveno zmanjša, pri posameznih pesmih celo izniči. 
Cikel Helena, kljub svoji konvencionalnosti, jasno napoveduje spremembo v opisovanju in dojemanju ženskega lika in njenega hotenja, ki svoj vrhunec doseže v Dunajskih večerih.

»Kjé je pomlad, kjé je dekle moje!«

Drugi cikel Erotike, Iz lepih časov je kronološko po času nastanka najstarejši, o čemer priča tudi sama zgradba pesmi, ki so sicer precej bolj podobne zgodnjim romantičnim pesnitvam. Cikel je sestavljen iz dveh delov, v prvem delu imamo pesmi, ki so že samo po obliki (metrum, kitična zgradba, rima) bližje romantični poeziji, kot moderni. Tudi ženska je v tem ciklu slikana enako kot v pesmih, ki so izhajale posamično pred Erotiko. Manjši premik tako v obliki, kot v pojmovanju ženske je narejen v drugem delu, ki je posvečen Ani Lušinovi. V njem se tudi prvič dokaj jasno nakažejo posamezni erotični prizori med moškim in žensko.

\section{»Oj ti grešnica krasna ...«}

Pravi prelom v dojemanju ženske pa predstavlja najbolj kontroverzni, tretji cikel Erotike, Dunajski večeri. V njem podoma ženske doživi popolno osvoboditev. V drugi pesmi cikla prevzame celo vlogo lirskega subjekta, ki ljubimca nagovarja k spolnosti in s tem postane nama subjekt. Ženska ni več en in isti nedotakljivi ideal ali preprosto veselo dekle, ampak prevzame najrazličnejše vloge od ljubice, matere, prešuštnice, prostitutke do Madone. V vseh pogledih njena podoba izenači z moški oziroma je njeno čustvovanje in doživljanje pomembno bolj kot njegovo. Za ponazoritev napisanega vzemimo peto pesem cikla:

5.

Pod oblačnim, sivim nebom

sanjala je noč jesenska;

ali midva, roko v roki

na divanu sva sedela.

»Ne poljubljaj, ne objemlji, ne govori, da me ljubiš ...

S svojo strastjo nepošteno pogubila si mi dušo.

Na pohotnih tvojih ustnih, v poželjivih tvojih rokah stopa prédme v rožnem svitu zapuščeno dekle moje. 
S strahom, studom gleda náme

njen nedolžni, gorki pógled ...

,Ah, kakó je mrzlo, temno

tu pri tebi, ljubček moj! ...'

Dà, temnó je vse krog mene,

v srcu mojem temno, prazno;

in zagrnil bi si lice

od sramote, od kesanja.»»

Temni kodri so se vili

nad obràzom njenim belim;

kot dva črna diamanta

sta goreli ji očesi.

»Ne govôri, ne očitaj! ...

Ti me hočeš ... ti me ljubiš;

s svojo strastjo nepošteno

ti pogubil si mi dušo; -

In temnó je vse krog mene, temno, prazno v srcu mojem

kadar plaka moja mati

in preklinja me moj mož.«

(Cankar 1967: 62-63)

V zgornji pesmi, jasno vidimo, da je pesnik ob bok moškemu, na isto mesto postavil žensko. Gre za dvogovor, ki se začne z moškim in konča z ženskim govorom. Oba govora sta si po vsebini zelo podobna, saj se oba znajdeta $\mathrm{v}$ enaki situaciji nezvestobe. $\mathrm{S}$ tem, ko pesnik da besedo tudi ženski, pusti, da ta pride $\mathrm{v}$ središče in bralcu razkrije svoje misli, občutja in, kar je najpomembnejše, svojo slo in hotenja . To, da je kot sogovorko uporabil nezvesto ženo, ki se svojih dejanj in posledic le-teh zelo dobro zaveda, lahko razumemo kot popoln odklon od romantične podobe ženske. Ženska v romantiki je bila običajno prikazana kot nedolžna deklica, na katero je moški gledal kot na prešuštnico že če je pomislila na katerega drugega moškega ${ }^{28}$, če pa je moža prevarala tudi v resnici, jo je doletela strašanska (božja) kazen. Tako jasne besede varajoči ženski ni dal nihče vse do Cankarja v Erotiki in Župančiča v Čaši opojnosti. S tem dejanjem sta Župančič in Cankar v literaturo spustila povsem nov pogled, ki se je pred tem skrival v ozadju. Ženska je nehala biti objekt, ampak je postala čuteč subjekt, ki čuti enako kot moški, torej vse od ljubosumja, pohote - do ljubezni.

${ }^{28}$ Glej Prešernovo pesem Pod oknam 
Cikel Dunajski večeri je najbolj dekadenten in senzualen v celotni Erotiki, zato je med ljudmi, ki niso bili vajeni tako eksplicitnega izražanja in navsezadnje tudi nespodobnega prikazovanja ženske, ki je žena in mati, izzval veliko neodobravanja. Prav o zgoraj omenjeni pesmi je Fran Govekar v pismu Antonu Aškercu pisal tako:

»Prostitucijo in prešestvo opevati v $4-5$ kiticah se mi zdi skoro nemožno, ker nedostaja blažilnih momentov na vseh krajih. In n. pr. tista pesem (»Ne vstajaj, ne vstajaj«), ko sta prešestnica in pešestnik skupaj - kje? i to pové pesnik! - ,ko trka nekaj (dež) na okno ter se ona vsa v strahu izvija (!) njegovemu objemu (!!), a prešestnik jo tolaži; 'tvoj mož pijančuje, bodi mirna!' - ta pesem se mi zdi naravnost grda, nepoetična. Manjka ji morale, manjka etičnega ozadja. Če je mož pijanec in morda celó surovak, to še nikakor ne ublaží greha žene - matere! Niti glad bi ne bil v pesni (!!) dovolj močan motiv, da se uda mati prostituciji ... Ali se motim?? - In taka je večina tistih pesmij. Sama poltnost brez dovelj krepkih blažilnih stranij! Menim torej, da bi C. storil prav, če te pesmi - vsaj za nekaj let - odloži, pa izpusti iz nameravane zbirke! - Jaz bi mu svetoval to, a fant bi me ne ubogal, ker je prav v to zbirko ves zaljubljen.« (Cankar 1967: 326-327)

To Govekarjevo pismo dokazuje, kakšno revolucijo v dojemanju ženske je povzročila objava Dunajskih večerov. Pomisliti na to, da je ženska več kot samo mati, žena in devica je bilo nezaslišano. Pomisliti na to, da si ženska želi kaj drugega kot biti mati, žena ali devica je bilo nezaslišano. Ženska je z Dunajskimi večeri prvič v liriki doživela svobodo, privilegij, da je zgolj in samo ženska.

»Ah nagni k meni, sulamit, prebele prsi svoje ...«

Četrti del Erotike sestavlja cikel pesmi Romance, v katerem nastopajo predvsem znane zgodovinske osebnosti (filozofi, preroki, vladarji). V tem delu prevladujejo epske pesmi, ženska pa v vsem svojem dekadenčnem sijaju pride do izraza v prvi pesmi cikla Sulamit ${ }^{29}$, kjer Cankar opisuje dvor kralja Salomona. Canakr slikovito opisuje telesa plesalk, njihovo pohoto in zapeljivosti, ki kralju Salomonu ne pride do živega. Edina, ob kateri mu uspe pozabiti na skrbi je njegova ljubica Sulamit. Ženska prespektiva v tej pesmi (in v ostalih iz tega cikla) ostaja skrita, zanimiva pa je za to, ker z natančnimi opisi ženskih teles, njihovega gibanja in poželenja, pesnik ženski vrne njeno (v pretekli liriki

${ }^{29}$ Sulamit iz Sulema je bila domnevna ljubica kralja Salomona, ki je omenjena v Visoki pesmi, katere avtorstvo nekateri pripisujejo prav kralju Salomonu. 
odvzeto) ženskost. Ženska je opisana kot privlačna in zapeljiva, kar je poudarjeno do te mere, da lahko njeno ženskost vidimo že mitologizirano. Če je pred Erotiko mit ženske utelešala trpeča mati ali požiralka moških preobleki device, sam pojem ženskosti pa je bil neobstoječ, pa je ravno v pesmi Sulamit (in delno tudi v nekaterih pesmih iz cikla $D u$ najski večeri) ženskost dobila v lirskem prostoru svoje mesto.

\section{Zaključek}

Pesniški opus Ivana Cankarja nam ponuja zelo jasen vpogled $\mathrm{v}$ razvoj dojemanja ženske in ženskosti v slovenski liriki. Njegove zgodnje pesmi so tako po obliki, kot po vsebini izrazito prešernovske in opisujejo žensko le kot mamo ali pa kot devico, ki svojo nedolžnost in nežen videz izrablja za igranje z moškimi. Tudi Cankarjeve prve, neobjavljene pesmi iz leta 1891 so napisane v tem duhu, ženska se v njegovi liriki oklepa tradicionalnih pričakovanj začne osvobajati postopoma. Njegov odnos do ženske se spremeni že v obdobju njegovega objavljanja pesmi okoli leta 1895, ko moški subjekt z ženskim objektom splete odnos in nanjo neha gledati kot ne nedosegljivi ideal, ki ga bo pokopal. Žensko v tem času tudi razbremeni absolutne krivde za svojo nesrečo.

O resnično velikem koraku za podobo ženske v literaturi pa lahko začnemo govoriti šele leta 1899, ko Cankar izda sporno zbirko Erotika. $\mathrm{V}$ tej zbirki ženska postane enako aktivna kot moški, postane enako čuteča, enako ali celo pomembnejša kot moški, predvsem pa prevzame vlogo subjkta, ki svetu sporoča, da je kljub svojemu spolu čuteče bitje, ki se zaveda odgovornosti za svoja dejanja in predvsem subjekta, ki se zaveda svojega telesa in njegovih hotenj. Ženska v pridobi nazaj svojo ženskost, ki je bila pred Župančičem in Cankarjem potisnjena popolnoma na rob. Iz edinih dveh vlog, ki jih je igrala v preteklosti, tokrat vloge naglo menja - od Madone do prostitutke, od vzorne matere in žene do prešuštnice, ki ljubimca nagovarja k spolnemu odnosu.

Seveda, je ta prelom v dojemanju ženske med Slovenci vzdignil veliko prahu, saj ti niso pričakovali njene podobe $\mathrm{v}$ drugih vlogah. Zgroženje ob izidu nekaterih pesmi Erotike nam lepo prikaže pismo Frana Govekarja Antonu Aškercu, v katerem se pisatelj zgraža nad pomanjkanjem morale in opisovanjem nedotakljivega mita matere in žene kot prešuštnice.

Cankarjeva lirika pa žensko pojmuje drugače tudi kot Cankarjeva drama in proza. Ženske so tam po večini na obrobju, če se znajdejo v središču pa utrjujejo mit zavoljo sinov odrekajoče se matere ali pa 
uvajajo koncept dekadenčne femme fatale, ki v svoje žrelo zvablja nič hudega sluteče moške in jih vodi v moralni, fizični in gmotni propad. Ženska v Cankarjevi liriki pa nasprotno dobi popolnoma drugo konotacijo iz mita preide $\mathrm{v}$ drug mit. Iz nedosegljivega, božanskega mita, preide $\mathrm{v}$ dosegljivo, čuteče, človeško bitje, ki postane mit ravno zaradi te svoje človeškosti in zavedanja le-te.

Ženska je po Cankarju v liriki še naprej zavzemala zelo pomembno mesto in postajala vedno bolj dosegljiva in manj vzvišena, kar je ljudi vzpodbudilo $\mathrm{k}$ razmišljanju o enakosti in pravicah. Osebno verjamem, da je najpomembnejši premik, ki sta ga storila Cankar in Župančič ta, da sta k razmišljanju o svojem položaju predvsem spodbudila ženske same, ki se razen izobraženk in predstavnic višjega sloja, prej niso ukvarjale s svojim položajem v družbi. Moderna je poleg revolucionarnih političnih misli, ljudem prinesla veliko več: nastavila jim je ogledalo in jih prisilila k razmišljanju o napredku. Seveda v tem kontekstu večinoma omenjamo Cankarjevo dramatiko in prozo, vendar je za feministično vprašanje $\mathrm{v}$ Sloveniji zelo pomembna tudi literatura. Zahvaljujoč predvsem Izidorju Cankarju in Antonu Aškercu, lahko preko neobjavljenih in objavljenih pesmi Ivana Cankarja lepo opazujemo ta prehod v dojemanju ženske od matere, preko vesele mladenke, do čuteče, z ženskostjo napolnjene ljubice.

\section{Viri in literatura}

Ivan CANKAR, 1967: Zbrano delo: Prva knjiga: Erotika 1899 / Objavljene nezbrane pesmi / Dodatek (Pesmi 1891 - 1893). Ljubljana: Državna založba Slovenije.

France BERNIK, 1968: "Problem Cankarjeve Lirike". Slavistična Revija, 16/1, 169-230. Splet. 25. 10. 2018.

Anton AŠKERC, 1899: »Erotika« pa »Čaša opojnosti«; Pismo iz Ljubljane. Ljubljanski zvon 19/6, 344-360. Splet. 26. 10. 2018.

Joža MAHNIČ, 1964: Zgodovina slovenskega slovstva. Ljubljana: Slovenska matica.

Alenka DOLEŽAL JENSTRLE, 2002: »Mitologizacija ženske v Cankarjevi prozi«. Simpozij Obdobja 21: Slovenski roman. Ur. Miran Hladnik in Gregor Kocijan. Ljubljana: Narodna in univerzitetna knjižnica, 109-119.

Anton SLODNJAK, 1968: Zgodovina slovenskega slovstva. Celovec: Drava.

France PREŠERN. »Pod oknam«. Splet. 25. 10. 2018. https:// sl.wikisource.org/wiki/Pod_oknom 


\title{
Eva Kryštufek
}

\section{THE IMAGE OF FEMALE CHARACTERS IN IVAN CANKAR'S LYRIC}

\begin{abstract}
Summary:
The article is dealing with the image of female character in Ivan Cankar's poetry. We chronologically follow development of female character, starting with Cankar's earliest, unpublished poems to his most significant poetry work - Erotika. The article focuses on Erotika in great details, as it unveils Cankar's personal attitude towards females social and personal role and also the Slovenian society's view on female figure, which explains the overwhelming reception of Erotika.

Key words: Ivan Cankar, Erotika, decadence, the female motif, Slovene poetry
\end{abstract}

